\title{
Biology and External Morphology of the Immature Stages of Dirphia moderata Bouvier (Lepidoptera: Saturniidae: Hemileucinae) in Anacardium occidentale L.
}

\author{
G. A. S. Gonçalves ${ }^{a, b *}$ (D) F. S. Barbosa ${ }^{a}$ (D) and M. Paluch alb $^{a}$ \\ ${ }^{a}$ Centro de Ciências Agrárias, Ambientais e Biológicas, Universidade Federal do Recôncavo da Bahia - UFRB, \\ Campus de Cruz das Almas, Rua Rui Barbosa, 710, Centro, CEP 44380-000, Cruz das Almas, BA, Brasil \\ ${ }^{b}$ Laboratório de Sistemática e Conservação de Insetos, Setor de Ciências Biológicas, \\ Universidade Federal do Recôncavo da Bahia - UFRB, Campus de Cruz das Almas, \\ Rua Rui Barbosa, 710, Centro, CEP 44380-000, Cruz das Almas, BA, Brasil \\ *e-mail: anygoncalves01@hotmail.com
}

Received: June 11, 2018 - Accepted: August 17, 2018 - Distributed: February 28, 2020

(With 6 figures)

\begin{abstract}
The genus Dirphia Hübner, [1819] presents Neotropical distribution. This genus, besides causing accidents of interest in public health, is a potential defoliator pest of cultivated plants, among them the cashew tree (Anacardium occidentale L.), a crop of great economic importance. This study describes the biology, external morphology of the immature stages of Dirphia moderata Bouvier, 1929 including the first instar larva chaetotaxy. The egg stage had an average duration of 15 days, larval stage 45 days and pupa 60 days, totaling 120 days in average temperature of $28.8^{\circ} \mathrm{C}$ and $59.5 \%$ relative humidity. Six instars were confirmed by the Dyar rule, with a growth rate of cephalic capsule $\mathrm{K}=1.4$ times per instar. The results found in the first instar chaetotaxy follow the general pattern known for Hemileucinae.
\end{abstract}

Keywords: chaetotaxy, ontogeny, moth, Neotropical.

\section{Biologia e Morfologia Externa dos Estágios Imaturos de Dirphia moderata Bouvier (Lepidoptera: Saturniidae: Hemileucinae) em Anacardium occidentale $\mathbf{L}$.}

\begin{abstract}
Resumo
O gênero Dirphia Hübner, [1819] apresenta distribuição Neotropical. Esse gênero, além de causar acidentes de interesse na saúde pública, é uma potencial praga desfolhadora de plantas cultivadas, entre elas o cajueiro (Anacardium occidentale L.), cultura de grande importância econômica. Esse estudo descreve a biologia e morfologia externa dos estágios imaturos de Dirphia moderata Bouvier, 1929 incluindo a quetotaxia da larva de primeiro instar. O estágio de ovo teve duração média de 15 dias, estágio larval de 45 dias e pupa de 60 dias, totalizando 120 dias em temperatura média de $28,8^{\circ} \mathrm{C}$ e $59,5 \%$ de umidade relativa. Seis ínstares foram confirmados pela regra de Dyar, com razão de crescimento da cápsula cefálica $\mathrm{K}=1,4$ vezes a cada ínstar. Os resultados encontrados na quetotaxia do primeiro ínstar segue o padrão geral conhecido para Hemileucinae.
\end{abstract}

Palavras-chave: quetotaxia, ontogenia, mariposa, Neotropical.

\section{Introduction}

The insects associated with major crops are grouped according to their food behavior (Hoffmann-Campo et al., 2012). Formentini et al. (2015) studying the order Lepidoptera as an agricultural pest, reported that more than half of the species of agronomic interest are polyphagous. Among Saturniidae, several species of different genera are found in cultures, such as sugarcane (Saccharum officinarum L.), eucalyptus (Eucalyptus spp.), guava (Psidium guajava L.) and cashew (Anacardium occidentale L.), causing damages to these crops (Dias, 1988; Pereira et al., 2008a, b).
The genus Dirphia Hübner [1819] (Saturniidae: Hemileucinae) has a wide distribution in the Neotropical region, including 41 species, of which 21 occur in Brazil (Mielke and Moser, 2007). Dirphia moderata Bouvier, 1929 occurs to the Brazilian South, Southeast and Northeast regions (Lemaire, 2002; Mielke and Moser, 2007; Santos et al., 2011), is highlighted by several studies as a leaf eating caterpillar on different host plants of economic interest, among them A. occidentale, Schinus terebinthifolius Raddi, Spondia mombin (L.) (Anacardiaceae), Rapanea umbellata 
(Mart.) Mez (Myrsinaceae), Eucalyptus cloeziana F. Muell and P. guajava (Myrtaceae) (Dias, 1988; Pereira et al., 2008a,b; Marques et al., 2009; Santos et al., 2011).

In relation to the taxonomy and systematics of large groups, the representatives of the Saturniidae family are the most well studied, together with the families Sphingidae and Erebidae (Arctiinae) (Stehr, 1987; Moraes et al., 2017). Despite the great relevance of such studies, records of immature stages, which are fundamental for strengthening taxonomy data and supplementing the phylogeny of this group, are scarce, making it difficult to study comparatively the biology and morphology of immature individuals (Hasenfuss and Kristensen, 2003).

Some studies show detailed morphological characters of immature stages of Saturniidae including first-instar larva chaetotaxy, classification of larval external structures (chalazae, scoli, verrucae, and spinules), morphology and sexual dimorphism in pupae, however, most contemplates these aspects partially (Pease, 1960; Zanuncio et al., 1994; Lorini, 1999; Lorini and Corseuil, 2001; Deml and Dettner, 2002; Furtado, 2002; Rougerie and Estradel, 2008; Specht et al., 2006a, b, 2007a, b, 2008, 2009, 2010, 2011, 2012; Zenker et al., 2013; Albertoni and Duarte, 2015; Moraes et al., 2017).

In view of the importance of biology and morphology studies of immature stages for the systematics of the Hemeulicinae group, thus reinforcing the taxonomy of the genus Dirphia, as well as subsidies for a proper management of species with economic interest, this study aims to describe the biology and the external morphology of immature stages of D. moderata, including chaetotaxy of the first instar.

\section{Material and Methods}

Cashew leaves (A. occidentale) were sampled in the municipality of Cruz das Almas, Bahia, Brazil (S $12^{\circ} 40^{\prime} / \mathrm{W} 39^{\circ} 06^{\prime}$ ), to obtain eggs of D. moderata between October and November 2016. In the Laboratório de Sistemática e Conservação de Insetos (LASCI), Setor de Ciências Biológicas (SCB), Centro de Ciências Agrárias, Ambientais e Biológicas (CCAAB), UFRB, the collected eggs were kept in Petri dishes with filter paper slightly moistened for incubation. After hatching, the larvae $(n=50)$ were fed with branches of cashew and bred in cages up to the sixth instar. In the pre-pupal period, the larvae were individually transferred to $500 \mathrm{ml}$ translucent plastic bottles containing a perforated lid and food, and later the pupae were kept in the dark until the emergence of adults. They were sacrificed and fixed in an entomological collection for other morphological studies. All development stages were monitored in laboratory conditions with daily temperature and relative humidity recording using a digital thermo-hygrometer.

The cephalic capsules were collected after each ecdysis and preserved dried in properly labeled vials. Eggs, larvae and pupae (voucher material) were fixed in Dietrich solution and later preserved in $70 \%$ ethanol.

Measurements of larval body length were carried out at each instar and, afterwards, the length and width of pupae were measured using a digital pachymeter. For the head, we used an Olympus SZX7 trinocular stereomicroscope with a 56X magnification coupled to an Olympus SC30 video camera and the imaging software cellSens, using the largest head width in frontal view. The length of the larvae body followed the measurement between the frontal region of the head and the suranal plate. The largest pupae width was measured ventrally, in the middle region, between the posterior wings, and the length was measured from the anterior margin of the head to the end of the cremaster.

The photographic records of first instar larvae and the pupa were performed using a Zeiss Discovery V20.0 stereomicroscope with a coupled camcorder; for the eggs and larvae of the $2^{\text {nd }}$ to the $6^{\text {th }}$ instar, an Olympus digital camera was used.

The growth rate of the cephalic capsule was determined based on the Dyar rule, according to Parra and Haddad (1989). The description of the pupa and the of chaetotaxy of first instar larvae was carried out according to Mosher (1914, 1916), Stehr (1987), Wolfe and Balcázar-Lara (1994) and Moraes et al. (2017). The voucher material was deposited at the collection of Insects of Museu de Zoologia e Paleontologia da Universidade Federal do Recôncavo da Bahia (MURB), SCB, CCAAB, UFRB, Cruz das Almas, Bahia, Brazil.

\section{Results}

\subsection{Life cycle of D. moderata}

Fifty eggs were selected from laboratory breeding. After 15 days, all larvae hatched. In the first few hours, first instar larvae fed on the corium and remained on the abaxial surface of the same leaf, beginning the consumption of the whole leaf limb in a few hours. Larvae are gregarious in all instars and move in a row (processionism), feeding on the entire leaf limb mainly during the night. From hatching until they pupation, the larval stage performed five ecdysis, finally reaching the sixth instar. All the development of D. moderata lasted (egg-larva-pupa) 120 days at an average temperature of $28.8^{\circ} \mathrm{C} \pm 3.97$ and a humidity of $59.5 \pm 0.16$.

The molt process was similar in all instars. Approximately one day before the molt, the larvae stopped feeding and the gregarism remained stationary until the molt, eliminating the exuviae after approximately 24 hours, and then resuming feeding. At the end of the sixth instar, in the pre-pupae period, the larvae reduced in size, darkened the body color, and the gregarism ended. In the flasks, each larvae, before pupation, united the leaves of the host plant or the leaves near the flask wall with silk, pupation occurs inside a cocoon of yellowish silk poorly organized. 


\subsection{External morphology of the immature stages of D. moderata}

Egg (Figure 1a, b). The laying is of the composite type, so they are easily recognized on the green background of the leaf substrate. On average, $74.4 \pm 23.52$ eggs $(n=6)$ are laid side by side on plates on the abaxial surface of younger leaves in cashew branches. The eggs are ellipsoidal and well conspicuous, with a mean width of $1.6 \pm 0.06 \mathrm{~mm}$ and a mean height of $1.8 \pm 0.16 \mathrm{~mm}(\mathrm{n}=39)$. There is
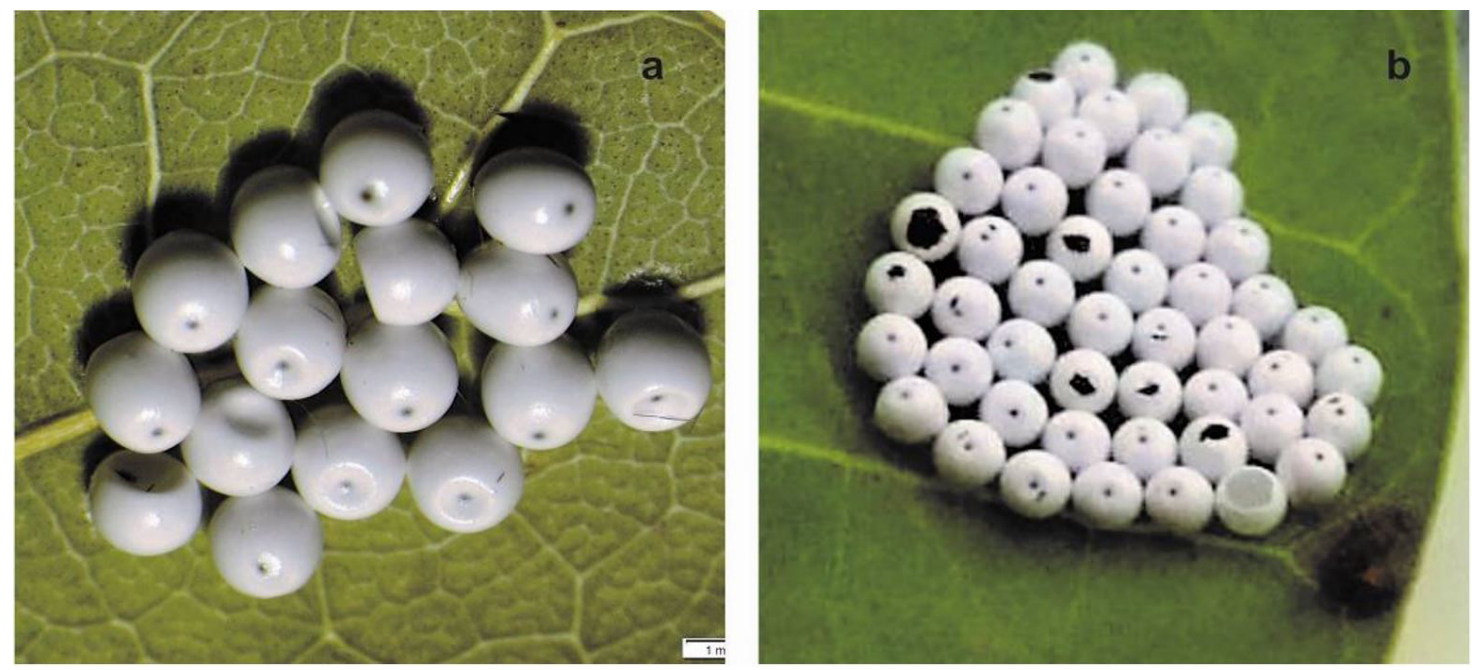

Figure 1. Immature stages of Dirphia moderata Bouvier. (a) Eggs, lateral-dorsal view; (b) Eggs and the beginning of the hatching of first instar larvae.

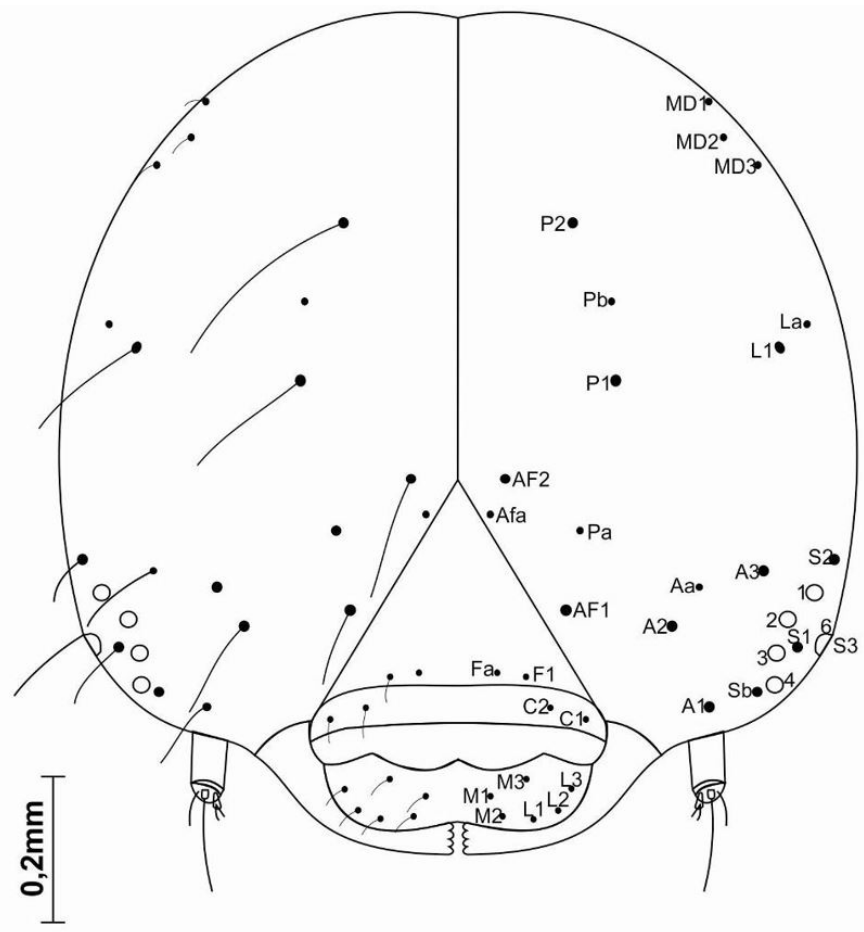

Figure 2. Chaetotaxy of the head of the first instar larvae of Dirphia moderata Bouvier. 
dark brown peritreme marked externally by light yellow, prothorax plates, suranal and reddish brown larvopods, red-brown chalazae, translucent setae. Legs and reddish larvopods.

Round head, $1.1 \pm 0.06 \mathrm{~mm}$ wide $(\mathrm{n}=40)$. It has six stemae: 1, 2, 3, 4 in semicircle format, stema 6 parallel to the 3 , five are conspicuous in frontal view, except for the stema 5 distally to the antenna, evident in the ventral view (Figure 2). Epicranial suture 2 times the length of lateral adfrontal suture; sclerotized dark brown clypeus, light brown anteclypeus with a membranous aspect, bilobate brownish-brown labrum. Brown antennas, with three antennomers, the basal one wider, the second narrower than twice the length of the anterior, with the presence of two sensilla setae (lateral and middle), the third extremely reduced. The maxilla is composed of the laciniogaleae, maxillary palpi with three segments. Mandibles are symmetrical, serrated, with small teeth, and presence of two lateral setae. Labium with a pair of labial palpus each composed of two segments, evident spinneret.

Chaetotaxy (Figures 2 and 3). Head (Figure 2): In the cephalic capsule, there are 14 long and tactile setae, A1, A2, A3, S1, S2, S3, L1, P1, P2, AF1, AF2 are evident in frontal view, and SS1, SS2 and SS3 in the ventral view. The proprioceptor setae in the microdorsal group; MD1, MD2, MD3 are located posterior to the seta P2 and superior to the La pore. Presence of seven pores, five of which are visible in frontal view: $\mathrm{Fa}, \mathrm{AFa}, \mathrm{Pa}, \mathrm{Pb}, \mathrm{La}$, and two pores in ventral view, Sa anterior to the seta S3 and MGa near the margin of occipital foramen. In the posterodorsal group, the seta $\mathrm{P} 1$ is above the pore $\mathrm{Pa}$, the $\mathrm{P} 2$ is dorsal and close to the epicranial suture above the $\mathrm{Pb}$ pore. In the frontal group, the pair of F1 setae close to the clypeus below the Fa pore; in the adfrontal group, the seta AF1 is close to the medial portion of the lateral adfrontal suture, the AF2 is near the epicranial-adfrontal suture junction, and the pore $\mathrm{AFa}$ is below it. In the clypeal group, the setae $\mathrm{C} 1$ and $\mathrm{C} 2$ are seen on the side. Labrum with L1, L2 and L3 setae present in the lateral portion of the lobes, and M1, M2 and M3 in the medial portion, in triangulation. In the stemmatal group, there are the seta $\mathrm{S} 1$, located between the 3 and 6, the S2 seta above the stema 1, the S3 seta posterior to the stema 6 , the pore Sa between the seta S3 and the stema 6. In the substemmatal group SS1, SS2 and SS3, there are similar sized setae, located ventrally: SS1 near the margin of the antennal socket, SS2 close to the stema 5 , and SS3 in the most distal portion. These three setae are in triangulation. It was not possible to observe the MDa, MG1 and SSa pores.

Thorax (Figure 3): Segment T1 with 11 pairs of setae (D1, D2, XD1, XD2, SD1, SD2, L1, L2, SV1, SV2 and V1), setae D1 and D2 with a same size coming out directly from the prothoracic plate right after XD1 and XD2 inserted on a bifurcated chalaza. Setae SD1 and SD2 in a single similar but smaller chalaza. L1 and L2 a little above the spiracle inserted in a small chalaza, L2 located in the middle portion. SV1 and SV2 coming out of a small chalaza above the prothoracic leg, SV2 posterior to SV1; V1 as a single bristle after the prothoracic leg. Segments T2 and T3 with 7 pairs of setae (D1, D2, SD1, SD2, L, SV and V1) follow the same distribution pattern of T1 with differences in some points, such as the setae D1 and D2, coming out of a bifurcated chalaza, Lateral seta L coming out of a small elongated chalaza. Subventral SV in a thick chalaza. V1 seta after the meso and metathoracic legs.

Abdomen (Figure 3): Chaetotaxy in segments A1, A2 with 8 pairs of setae (D1, D2, SD, L1, L2, SV, V1 and V2), A7 similar, however seta V2 absent in this segment. D1 and SD setae coming out of elongated chalaza without bifurcation, D2 near D1 exiting directly from the wall of the body, as well as the bristle V1 and V2, evident in the ventral part of each segment below the SV seta inserted in a thick chalaza. Setae L1 and L 2 coming out of a small bifurcated chalaza. The morphology of the A3-A6 segments is similar, with 6 pairs of setae (D1, D2, SD, L1, L2 and V1), following the same pattern of A1, A2 and A7, except for the absence of the SV group and the presence of the seta V1 inserted in the lateral plate of larvopod. Segment A8 with 7 pairs of setae (D1 + D1 (fused), D2, SD, L1, L2, SV and V1), similar to that found in the segments A1-2, A7 except D1 setae fused to a sturdy and forked chalaza located in the dorsal longitudinal line. Segment A9 with 5 pairs of setae (D1 + D1 (fused), D2, SD, SV and V1), with D1, SD, SV, V1 similar to A8, however D2 setae coming out of elongated chalaza without bifurcation. Lateral seta $\mathrm{L}$ absent in this segment. Segment A10 with 5 pairs of single setae in the suranal plate (D1, D2, XD1, SD1 and SD2), D1 and D2 of equal size forming a triangulation with XD1, SD1 just above SD2. In the lateral plate of the larvopod, there are 5 setae (PP1, L1, L2, SV1, SV2), PP1 at the posterior basal end of the plate, followed by SV1 and SV2, above SV1, L2 and L1 aligned in the medial portion of the plate. V1 seta in the pre-plate integument.

Second instar (Figure 4d-f). Larvae with an average length of $11 \pm 0.494 \mathrm{~mm}(\mathrm{n}=21)$ and with a duration of 6 days at a mean temperature of $28.1 \pm 4.31{ }^{\circ} \mathrm{C}$ and humidity of $65.0 \pm 0.18 \%$. Cephalic capsule measuring $1.5 \pm 0.23 \mathrm{~mm}(\mathrm{n}=42)$, dark red. Thoracic and abdominal integument dorsolaterally marked by reddish-brown, yellow-clear and black transverse discontinuous lines, ventrally reddish. Spiracle with dark brown peritreme marked internally by light yellow, plates and reddish brown body scoli, translucent bristles. Red-dark legs and larvopods.

Third instar (Figure 4g-i). Larvae measuring on average $17.2 \pm 0.15 \mathrm{~mm}(\mathrm{n}=21)$ with duration of 5 days at an average temperature of $28.7 \pm 4.91{ }^{\circ} \mathrm{C}$ and humidity of $63.0 \pm 0.29 \%$. Cephalic capsule with $2.2 \pm 0.09 \mathrm{~mm}(\mathrm{n}=39)$. Head coloration, thoracic and abdominal integument, legs and larvopods similar to the $2^{\text {nd }}$ instar.

Fourth instar (Figure 5a-c). Larvae measuring on average $24.6 \pm 0.36 \mathrm{~mm}(\mathrm{n}=21)$ with duration of 5 days at an average temperature of $29.8 \pm 4.23{ }^{\circ} \mathrm{C}$ and humidity of $62.0 \pm 0.24 \%$. Cephalic capsule measuring $2.8 \pm 0.17 \mathrm{~mm}$ $(\mathrm{n}=37)$. Color of head, plates, scoli, legs and larvopods similar to $3^{\text {rd }}$ instar. Thoracic and abdominal integument 


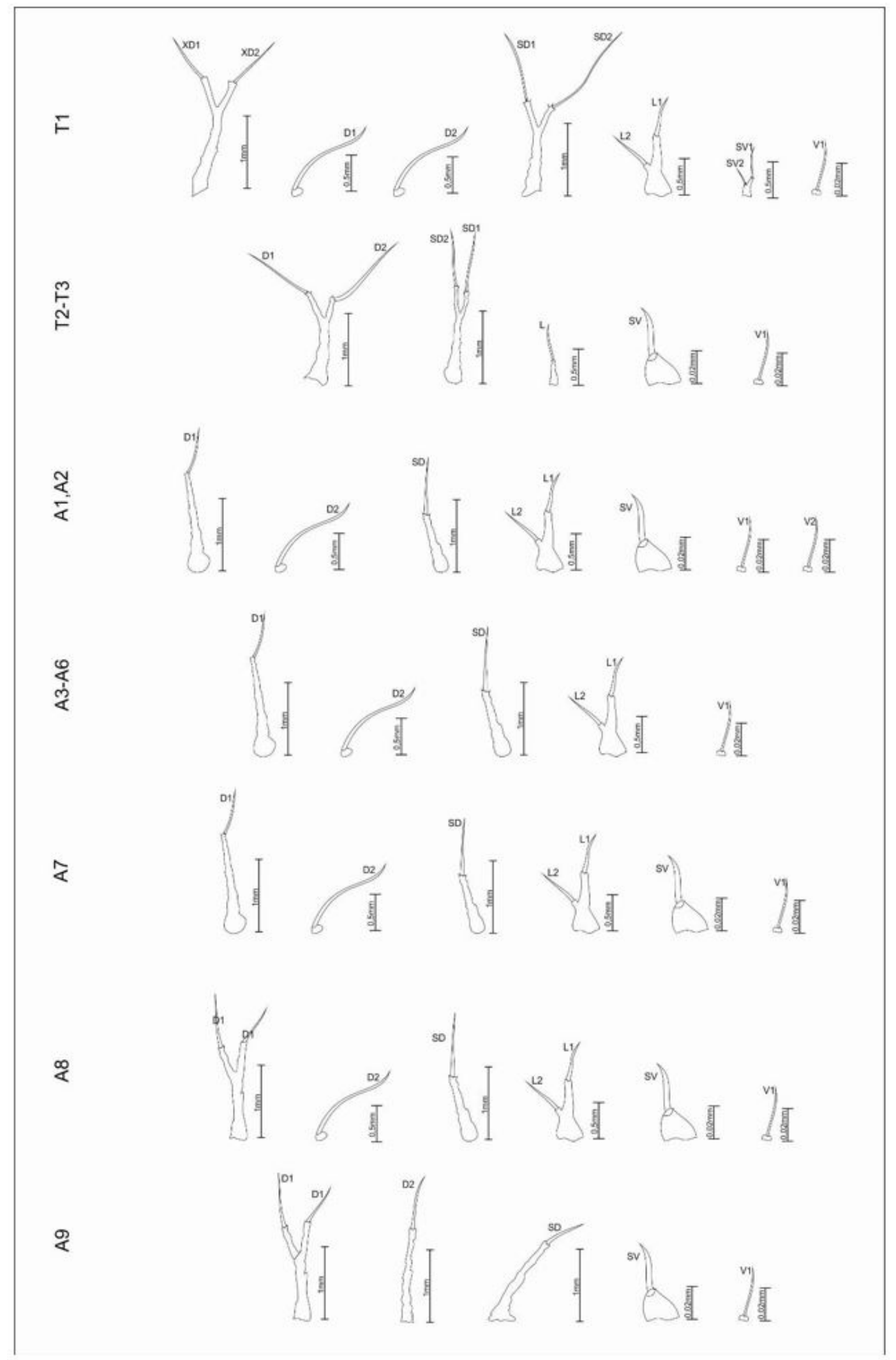

Figure 3. Chaetotaxy of the thorax (T1-T3) and abdomen (A1-A9), setae and chalazae of the first instar larvae of Dirphia moderata Bouvier. 

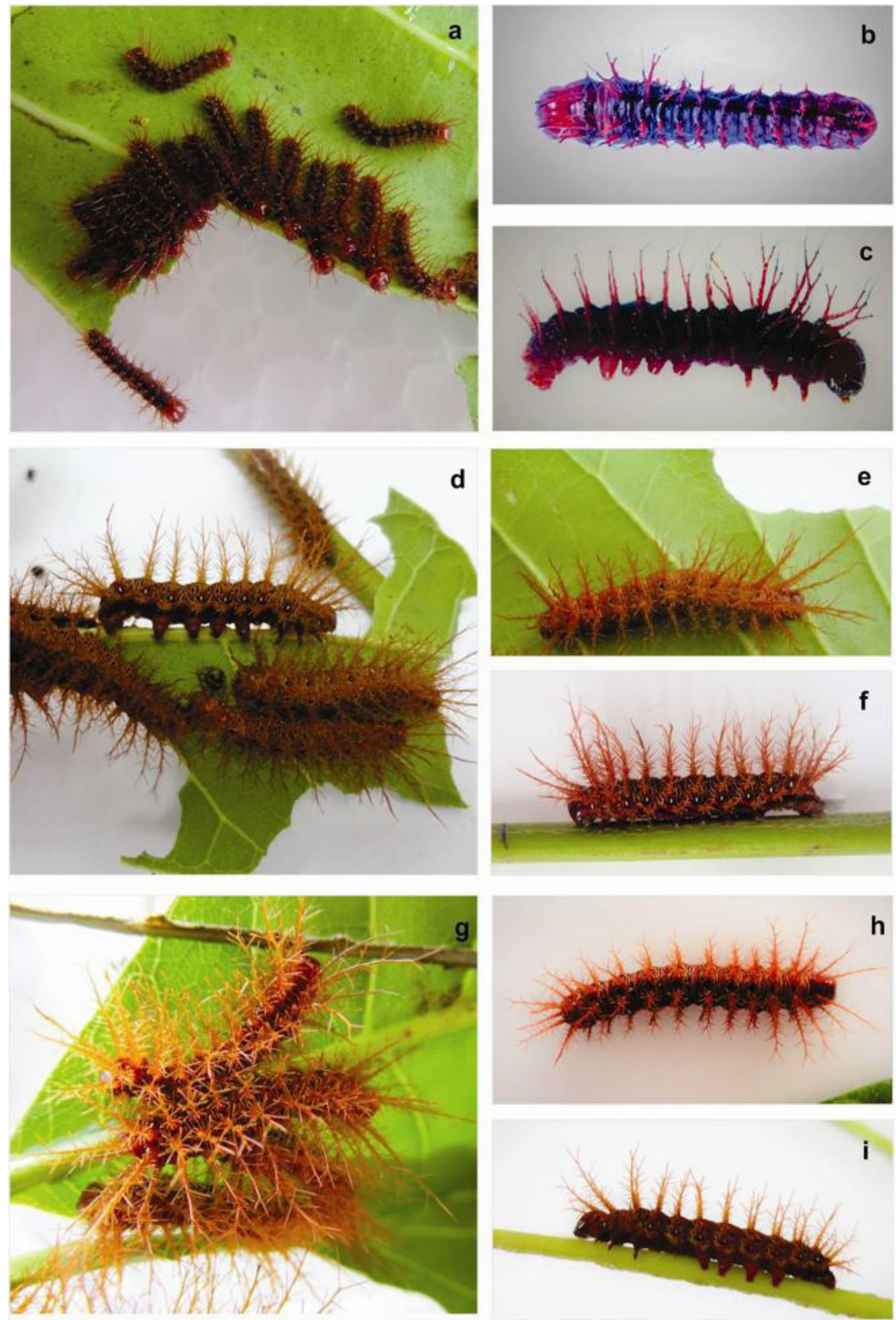

Figure 4. Immature stages of Dirphia moderata Bouvier. (a) First instar gregarism; (b) First instar, dorsal view; (c) First instar, lateral view; (d) Second instar gregarism; (e) Second instar, dorsal view; (f) Second instar, lateral view; (g) Third instar gregarism; (h) Third instar, dorsal view; (i) Third instar, lateral view. 

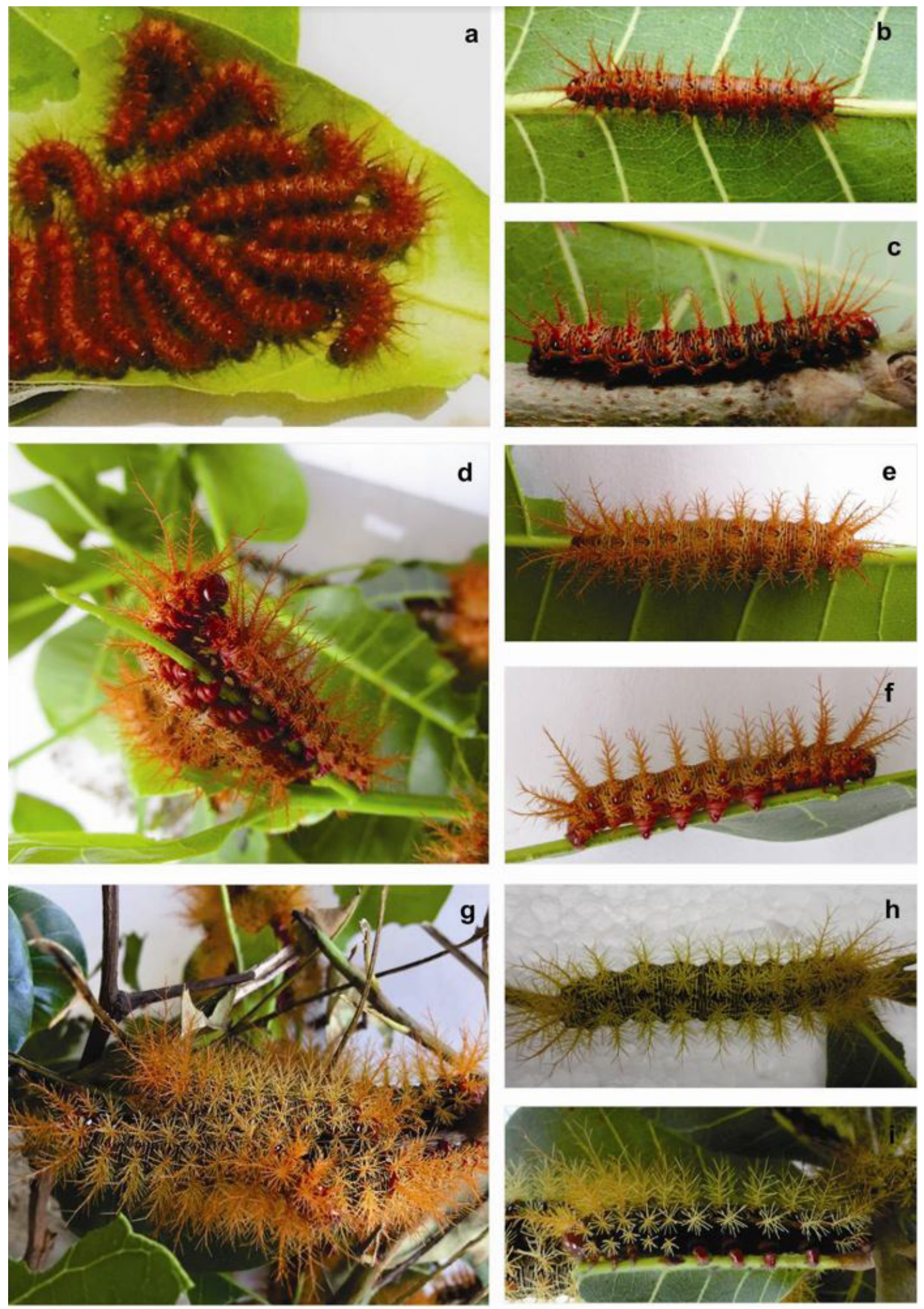

Figure 5. Immature stages of Dirphia moderata Bouvier. (a) Fourth instar gregarism; (b) Fourth instar, dorsal view; (c) Fourth instar, lateral view; (d) Fifth instar gregarism; (e) Fifth instar, dorsal view; (f) Fifth instar, lateral view; (g) Sixth instar gregarism; (h) Sixth instar, dorsal view; (i) Sixth instar, lateral view. 
with transverse discontinuous lines more distinct as to the separation of colors.

Fifth instar (Figure 5d-f). Larvae measuring on average $37.6 \pm 0.67 \mathrm{~mm}(\mathrm{n}=21)$ with duration of 7 days at an average temperature of $27.7 \pm 4.34{ }^{\circ} \mathrm{C}$ and humidity of $67.0 \pm 0.21 \%$. Cephalic capsule measuring $3.8 \pm 0.28 \mathrm{~mm}$ $(\mathrm{n}=27)$. Color of head, plates, scoli, legs and larvopods similar to $4^{\text {th }}$ instar. Thoracic and abdominal integument dorsolaterally lighter than the anterior instar, with decrease of black color and intensification of yellow and reddish brown.

Sixth instar (Figure 5g-i). Larvae measuring on average $52.6 \pm 0.59 \mathrm{~mm}(\mathrm{n}=21)$ with duration of 12-17 days at an average temperature of $28.9 \pm 0.15{ }^{\circ} \mathrm{C}$ and humidity of $69.0 \pm 0.16 \%$. Cephalic capsule measuring $6.3 \pm 0.28 \mathrm{~mm}$ $(n=15)$, reddish-brown. Thoracic and abdominal integument dorsolaterally marked by yellow and black transverse discontinuous lines, ventrally black-velvety with red spots. Spiracle with black peritreme marked internally by white color. Plates, legs and larvae are reddish-brown, translucent bristles are yellowish. In relation to the previous instar, there is intraspecific variation in the staining of the scoli; in the segments T3-A5, they change to yellowish tones (Figure $5 \mathrm{~g}$ ). Some specimens may present all yellowish scoli (Figure 5 h-i).

Identification of the larval instars. The identification of larval instars by staining and by the structures of $D$. moderata are easily differentiated in the first and last instar. However, between the $2^{\text {nd }}-5^{\text {th }}$ instars, differences are little evident, making identification difficult. However, measurements of cephalic capsule width may ensure a correct identification of all six instars larvae through growth rate. $D$. moderata presented a mean growth of the cephalic capsule $(\mathrm{K})$ equal to $1.4 \mathrm{~mm}$ (Table 1$)$, which is within the tolerance range $(1.1 \mathrm{~mm}$ to $1.9 \mathrm{~mm})$ by the Dyar rule (Dyar 1890), confirming six instars for this species of the genus Dirphia.

Pupa (Figure 6a-c). Measures on average $11.7 \mathrm{~mm}$ in width and $30.5 \pm 2.90 \mathrm{~mm}$ in length $(\mathrm{n}=13)$, with a duration of 54 to 65 days until emergence, at an average temperature of $28.5 \pm 4.01{ }^{\circ} \mathrm{C}$ and humidity of $52.0 \pm 0.11 \%$. With

Table 1. Mean and standard deviation of cephalic capsule size $(\mathrm{mm})$ and growth rate $(\mathrm{K})$ among the six instars of Dirphia moderata Bouvier.

\begin{tabular}{ccc}
\hline Instar & $\begin{array}{c}\text { Mean width and } \\
\text { standard deviation } \\
\text { of the cephalic } \\
\text { capsule (mm) }\end{array}$ & $\begin{array}{c}\text { Growth rate of } \\
\text { cephalic capsule } \\
\text { (K) }\end{array}$ \\
\hline I & $1.1 \pm 0.02$ & - \\
II & $1.5 \pm 0.23$ & 1.4 \\
III & $2.2 \pm 0.09$ & 1.4 \\
IV & $2.8 \pm 0.17$ & 1.4 \\
V & $3.8 \pm 0.28$ & 1.4 \\
VI & $6.3 \pm 0.28$ & 1.4 \\
\hline
\end{tabular}
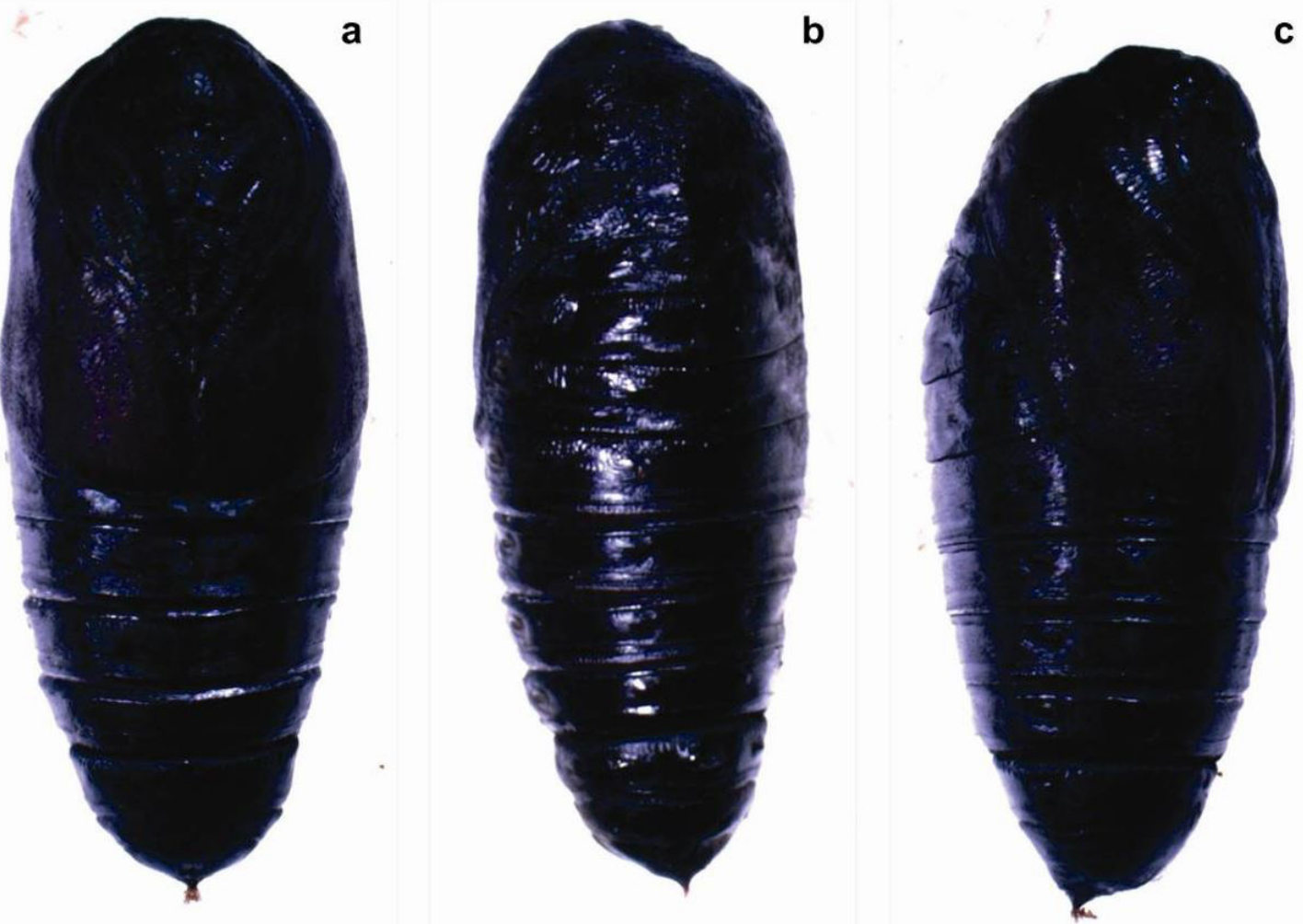

Figure 6. Immature stages of Dirphia moderata Bouvier. (a) Pupa, ventral view; (b) Pupa, dorsal view; (c) Pupa, lateral view. 
a cylindrical shape tapering in the posterior portion, the pupa has a rough general appearance of body integument, mainly in the cephalic, thoracic and appendices areas, initially opaque dark brown, turning black. It has its appendages firmly fused to the body wall. Head with frontal clypeus presenting slight longitudinal grooves delineated ventrally by the labrum and laterally by the eyes, semicircular, piliferous labrum with small tubers on the sides of the labrum, reduced gellules reaching the end of the mesothorax, antennas curved to the ventral region of the body. The antennas are rough, with segmentation marked by stretch marks, elliptical and rough eyes. Thorax segments visible in the lateral and dorsal view with pro- and mesonotum of integument rougher than the metanotum. As for the thoracic appendixes, the end of the prothoracic leg extends until the end of the first abdominal segment (A1) and the mesothoracic segment to the spiracle of A2. The legs are not separated by galeae and have marks of transverse grooves; wings without obvious venation and partially wrinkled, hiding the segments ventrally. Ten abdominal segments marked with fine points and grooves, well defined elliptical spiracles visible between A2 and A8; ventrally, female genital orifice as a little slit between A8-A9 and male orifice circular at the posterior portion of A9; ventral anal orifice in the shape of an inconspicuous slit in A10; short cremaster with few simple, sharp and brownish hooks.

\section{Discussion}

The first studies on the duration of the immature stages of D. moderata (Dias, 1988; Zanuncio et al., 1994; Pereira et al., 2008a, b) recorded cycles with an average of 90-130 days for a complete development of immature stages, which corresponds to approximately 3.5 generations per year, and this same pattern was corroborated in this study for D. moderata in the municipality of Cruz das Almas, as previously determined for other species of the genus recorded in the literature, such as Dirphia arancariae Jones, 1908, and Dirphia dolosa Bouvier, 1929 (Specht et al., 2012; Zenker et al., 2013), with the same proportion of days of each stage and larval instars, except for pre-pupae and pupa, which may vary according to the host plant, as observed by Pereira et al. (2008b). This pattern of ontogeny of the immature stages has also been recorded for other genera of Hemileucinae, such as Lonomia Walker, 1855, Automeris Hübner [1819], and Periga Walker, 1855, specially for hot climates, characterizing such genera as multivoltine (Lorini, 1999; Specht et al., 2006b, 2007b, 2011).

In Hemileucinae, the incubation of eggs covers approximately $9 \%, 12 \%, 23 \%$ or $25 \%$ of immature development (Dias, 1988; Lorini, 1999, 2008; Specht et al., 2006b, 2007a,b, 2010, 2011), 12\% corresponds to a general pattern for genus Dirphia, according to Zanuncio et al. (1994); Pereira et al. (2008a,b) and Santos et al. (2011). D. moderata has an incubation period between 15 and 18 days, similar to D. dolosa (Specht et al., 2012), differing from the species D. araucariae, with an embryo period corresponding to
$16 \%$, with approximately 26 days of duration (Zenker et al., 2013). In general, egg morphology of $D$. moderata resemble those described for other species of the genus (Specht et al., 2012; Zenker et al., 2013).

In the subfamily Hemileucinae, the larvae are characterized by being gregarious, moving in individual lines in the nocturnal period (processionism). From the second to the sixth instar, they feed preferentially at night and form dense aggregations during the day, a behavior shown by $D$. moderata in laboratory and reported in the literature, including for other species of Dirphia (Dias, 1988; Zanuncio et al., 1994; Pereira et al., 2008a,b; Specht et al., 2012; Zenker et al., 2013), and also for other genera such as Hylesia Hübner, [1820] (Hemileucinae) (Fitzgerald and Pescador-Rubio, 2002; Specht et al., 2006a, 2007a).

At the end of the larval stage of Hemileucinae, in the pre-pupal phase (i.e., the end of the sixth instar), the larvae stop feeding and begin to wander in search of places to build their cocoons, during which time the larvae become smaller and darker (Specht et al., 2010). At this stage, larvae use silk threads to build their cocoon along with some leaves, forming a partially resistant and impermeable cocoon so that they may pupate, a behavior of the Molippa cruenta (Walker, 1855) that was also observed in D. moderata (Specht et al., 2010).

The larval stage may correspond to $40 \%, 48 \%, 55 \%$ or $70 \%$ of the life cycle of several species of Hemileucinae (Specht et al., 2006b, 2007a, b, 2010, 2011). After hatching, larvae of $D$. moderata present six instars, with a longer duration between the $4^{\text {th }}$ and $6^{\text {th }}$ instars. The whole period lasts on average from 53 to 56 days, $44 \%$ of the life cycle, as previously reported by Pereira et al. (2008a,b). This pattern has also been recognized for other genera of this subfamily, such as Hylesia (Specht et al., 2007a), Molippa Walker, 1855 (Specht et al., 2010) and for other species of Dirphia (Specht et al., 2012; Zenker et al., 2013).

For the subfamily Hemileucinae, are known two studies on chaetotaxy, for species Lonomia electra (Druce, 1886) and Gamelia anableps (C. Felder \& R. Felder, 1874) (Wolfe and Balcázar-Lara, 1994; Moraes et al., 2017). The number of setae found in the cephalic capsule of the first instar of D. moderata resembles those of L. electra and $G$. anableps. However, in D. moderata there was difference in location of setae MD group, arranged in an arch, with MD2 displaced towards the posterodorsal seta group, MD group was not illustrated in L. electra. As for pores, shown only in G. anableps, D. moderata with $\mathrm{Pa}$ pore below the $\mathrm{AFa}$; pore $\mathrm{Pb}$ between the setae $\mathrm{P} 1$ and $\mathrm{P} 2$; MDa pore absent and Fa pore above F1 seta.

In studies on chaetotaxy performed with Hemileucinae, only the primary setae are present in the form of single seta or arranged in chalazae (Pease, 1960; Moraes et al., 2017). According to Pease (1960), chalazae are very similar to scoli, but in the latter, primary and secondary setae cannot be differentiated. Scoli appear in D. moderata only after first ecdysis, in second instar larval, remaining until the sixth instar. The thoracic chaetotaxy of first instar of $D$. moderata resembles that of $L$. electra (Wolfe and 
Balcázar-Lara, 1994), however, the prothoracic plate of D. moderata beyond of the setae XD1, XD2, D1, SD1 and SD2 present also seta D2. The thoracic chaetotaxy G. anableps (Moraes et al., 2017) differs of the D. moderata by the presence of secondary setae in the chalazae $\mathrm{XD}, \mathrm{SD}$ and L. The abdominal chaetotaxy of $D$. moderata resembles that of L. electra (Wolfe and Balcázar-Lara, 1994), however, in the segments A1-A2, D. moderata differs only for presence of seta $\mathrm{V} 2$ and segments $\mathrm{A} 3-\mathrm{A} 6$ with absence of setae "SV group" and seta V1 inserted in the lateral plate of larvopod. The abdominal chaetotaxy G. anableps (Moraes et al., 2017) differs of the D. moderata by the presence of secondary setae in the D1, SD, L and SV in A7-A9; absence seta V2 in A1-A2; segment A9 with 6 pairs of setae, D2 with little seta inserted integument and presence of seta $\mathrm{L}$. The segment $\mathrm{A} 10$ follows the same pattern of L. electra and G. anableps with setae simple in the suranal plate and larvopod plate.

The morphological and coloring characters of the larval stage of $D$. moderata correspond to those described by Dias (1988). When compared to other known species of the genus, the first four instars are generally similar to those found in D. dolosa as illustrated by Specht et al. (2012). However, in a close analysis, they can be differentiated by the color of the head, details of ornamentation, color of the thorax-abdomen, and the pattern of the scoli.

An important factor for a better identification of each instar is the measurements of cephalic capsules. They can assure a correct identification of larval instars. Cephalic capsule width measurements recorded for $D$. moderata were similar to those described by Zenker et al. (2013) for $D$. araucariae, with an average growth rate of 1.42 .

The corresponding pupal period is approximately 50 days for Hemileucinae in general, when they do not enter the diapause period (Specht et al., 2010). In the laboratory, fed with cashew leaves, this stage lasted between 54-65 days. Zanuncio et al. (1994), breeding D. moderata on E. urophylla leaves, and Pereira et al. (2008b) breeding it on $P$. guajava leaves obtained 50 days. However, by feeding larvae with $E$. cloeziana leaves, a lower number was found (37 days), close to the results obtained by Santos et al. (2011) on leaves of S. mombin.

Although the pupae in the laboratory were bred in a same environment, not all of them evolved at the same time, which resulted in a variation in the period of pupal development. Zenker et al. (2013) pointed out a relation between temperature and the period of development of pupae, which, during the winter, go through a longer pupal stage, indicating that this species may present an optional diapause such as other Hemileucinae, as well as Automeris illustris (Walker, 1855) and Automoris naranja, Schaus, 1898 (Specht et al., 2006b, 2007b).

The pupal morphology of $D$. moderata they are according Dias (1988) and structurally resemble several Hemileucinae known in the studies of Mosher $(1914,1916)$ and Lemaire (2002). They have a rough texture similar to the pupa of D. araucariae (Specht et al., 2008), differing from the species Dirphia avia (Stoll, 1780), Dirphia panamensis (Schaus, 1921), Dirphia somniculosa (Cramer, 1777) (Lemaire, 2002) and Dirphia baroma (Schaus, 1906) (Specht et al., 2008), which have a smooth and shiny tegument. The absence of tubercles or spines in the thorax and abdomen; presence of a short cremaster with a few simple hooks, follow the pattern found in G. anableps (Moraes et al., 2017).

The data available for the studied populations of D. moderata in the southern and southeastern Brazil regions (Dias, 1988; Zanuncio et al., 1994; Santos et al., 2011) were corroborated in this study for the Northeast region, including the duration of the stages and the number of cycles during the year, despite the great climatic and environmental differences between these regions. This detailed study of the immature morphology of $D$. moderata presents subsidies to improve the systematics of Hemileucinae, as well as the agronomic management or conservation of this species.

\section{Acknowledgements}

To the Coordination for the Improvement of Higher Education Personnel (CAPES), by granting the master's degree scholarship to the first author.

\section{References}

ALBERTONI, F.F. and DUARTE, M., 2015. Immature stages of Adeloneivaia fallax (Lepidoptera: Saturniidae). The Florida Entomologist, vol. 8, no. 1, pp. 178-185. http://dx.doi. org/10.1653/024.098.0131.

DEML, R. and DETTNER, K., 2002. Morphology and classification of larval scoli of Saturniinae and Hemileucinae (Lepidoptera: Saturniidae). Journal of Zoological Systematics and Evolutionary Research, vol. 40, no. 2, pp. 82-91. http://dx.doi. org/10.1046/j.1439-0469.2002.00181.x.

DIAS, M.M., 1988. Estágios imaturos de Dirphia (Dirphia) moderata Bouvier, 1929 (Lepidoptera, Saturniidae). Revista Brasileira de Entomologia, vol. 32, no. 2, pp. 273-278.

DYAR, H.G., 1890. The number of molts of Lepidopterous larvae. Psyche, vol. 5, no. 175-176, pp. 420-422. http://dx.doi. org/10.1155/1890/23871.

FITZGERALD, T.D. and PESCADOR-RUBIO, A., 2002. The role of tactile and chemical stimuli in the formation and maintenance of the processions of the social caterpillar Hylesia lineate (Lepidoptera: Saturniidae). Journal of Insect Behavior, vol. 15, no. 5, pp. 659-674. http://dx.doi.org/10.1023/A:1020795806582.

FORMENTINI, A.C., SOSA-GÓMEZ, D.R., PAULA-MORAES, S.V., BARROS, N.M. and SPECHT, A., 2015. Lepidoptera (Insecta) associated with soybean in Argentina, Brazil, Chile and Uruguay. Ciência Rural, vol. 45, no. 12, pp. 2113-2120. http:// dx.doi.org/10.1590/0103-8478cr20141258.

FURTADO, E., 2002. Automerula auletes (Eric-Schäffer, 1854) e seus estágios imaturos (Lepidoptera, Saturniidae, Hemileucinae). Lambillionea, vol. 102, no. 1, pp. 110-112.

HASENFUSS, I. and KRISTENSEN, N.P., 2003. Skeleton and muscles: immatures. In: N.P. Kristensen, ed. Lepidoptera, moths and butterflies. Berlin: Walter de Gruyter, pp. 133-164.

HOFFMANN-CAMPO, C.B., FERREIRA, B.S.C. and MOSCARDI, F., 2012. Soja: manejo integrado de insetos e outros Artrópodes-praga. 1nd ed. Brasília: Embrapa, 859 p. 
LEMAIRE, C., 2002. The Saturniidae of America - Hemileucinae. Keltern: Goecke \& Evers, 1388 p.

LORINI, L.M., 1999. A taturana: Aspectos biológicos e morfológicos da Lonomia obliqua. Passo Fundo: EDIUPF, 67 p.

LORINI, L.M., 2008. Saturniidae, Hemileucinae - Lonomia obliqua Walker, 1855. In: A. SPECHT, E. CORSEUIL and H.B. ABELLA orgs. Lepidópteros de Importância Médica - Principais espécies no Rio Grande do Sul. Pelotas: USEB, pp.165-185.

LORINI, L.M. and CORSEUIL, E., 2001. Morfological Aspects of Lonomia obliqua Walker (Lepidoptera: Saturniidae). Neotropical Entomology, vol. 30, no. 3, pp. 373-379. http://dx.doi.org/10.1590/ S1519-566X2001000300006.

MARQUES, O.M., CARVALHO, A.J.A., SANTANA, M.J.S. and GIL-SANTANA, H.R., 2009. Registro de Dirphia avia (Stoll) e Dirphia moderata Bouvier (Lepidoptera: Saturniidae) no Estado da Bahia, Brasil. Magistra, vol. 21, no. 1, pp. 135-138.

MIELKE, C.G.C. and MOSER, A., 2007. Dirphia Hübner (Lepidoptera, Saturniidae, Hemileucinae): Descrição de uma espécie nova do Sul do Brasil e da Fêmea de D. rufescens F. Johnson \& Michener. Revista Brasileira de Zoologia, vol. 24, no. 2, pp. 319-322. http://dx.doi.org/10.1590/S0101-81752007000200008.

MORAES, S.S., OTERO, L.S. and FREITAS, A.V.L., 2017. Natural History and Comparative Morphology of Immatures of Gamelia anableps (C. Felder \& R. Felder) (Lepidoptera: Saturniidae, Hemileucinae). Neotropical Entomology, vol. 46, no. 4, pp. 397-408. http://dx.doi.org/10.1007/s13744-016-0473-z. PMid:27987160.

MOSHER, E., 1914. The classification of the pupae of the Ceratocampidae and Hemileucidae. Annals of the Entomological Society of America, vol. 7, no. 4, pp. 277-300. http://dx.doi. org/10.1093/aesa/7.4.277.

MOSHER, E., 1916. The classification of the pupae of the Saturniidae. Annals of the Entomological Society of America, vol. 9, no. 2, pp. 136-158. http://dx.doi.org/10.1093/aesa/9.2.136.

PARRA, J.R.P. and HADDAD, M.L., 1989. Determinação do número de instares de insetos. Piracicaba: Fealq. 49 p.

PEASE, R.W., 1960. A study of first instar larvae of the Saturniidae, with special reference to nearctic genera. The Lepidopterists Societ, vol. 14, no. 2, pp. 89-111.

PEREIRA, F.F., FELIPE, J.P.M., CANEVARI, G.C., MIELKE, O.H.H., ZANUNCIO, J.C. and SERRÃO, J.E., 2008a. Biological aspects of Dirphia moderata (Lepidoptera: Saturniidae) on Eucalyptus cloeziana and Psidium guajava. Brazilian Archives of Biology and Technology, vol. 51, no. 2, pp. 369-372. http:// dx.doi.org/10.1590/S1516-89132008000200017.

PEREIRA, F.F., ZANUNCIO, A.J.V., FELIPE, J.P.M., LORENZON, A.S. and CANEVARI, G.C., 2008b. Desenvolvimento e reprodução de Dirphia moderata (Lepidoptera: Satutniidae) em Eucalyptus cloeziana e Psidium guajava em laboratório. Revista Árvore, vol. 32, no. 6, pp. 1119-1124. http://dx.doi.org/10.1590/ S0100-67622008000600017.

ROUGERIE, R. and ESTRADEL, Y., 2008. Morphology of the preimaginal stages of the African emperor moth Bunaeopsis licharbas (Maassen and Weyding): phylogenetically informative characters within the Saturniinae (Lepidoptera: Saturniidae). Journal of Morphology, vol. 269, no. 2, pp. 207-232. http://dx.doi. org/10.1002/jmor.10562. PMid:17957713.

SANTOS, I.P.S., MIELKE, O.H.H. and LEMOS, R.P.L. and LIMA, I.M.M., 2011. Registro de Dirphia moderata (Lepidoptera: Saturniidae) em Spondias mombin (Anacardiaceae) e aspectos biológicos. Revista Chilena de Entomologia, vol. 36, no. 1, pp. 55-59.
SPECHT, A., FORMENTINI, A.C. and CORSEUIL, E., 2006a. Biologia de Hylesia nigricans (Berg) (Lepidoptera, Saturniidae, Hemileucinae). Revista Brasileira de Zoologia, vol. 23, no. 1, pp. 248-255. http://dx.doi.org/10.1590/S0101-81752006000100018.

SPECHT, A., FORMENTINI, A.C. and CORSEUIL, E., 2006b. Biologia de Automeris illustris (Walker) (Lepidoptera, Saturniidae, Hemileucinae). Revista Brasileira de Zoologia, vol. 23, no. 2, pp. 537-546. http://dx.doi.org/10.1590/S0101-81752006000200029.

SPECHT, A., FORMENTINI, A.C. and CORSEUIL, E., 2007a. Biological aspects of Hylesia metapyrrha (Lepidoptera: Saturniidae: Hemileucinae), in laboratory. Brazilian Journal of Biology $=$ Revista Brasileira de Biologia, vol. 67, no. 1, pp. 173-177. http://dx.doi.org/10.1590/S1519-69842007000100024. PMid:17505766.

SPECHT, A., FORMENTINI, A.C. and CORSEUIL, E., 2007b. Biologia e aspectos morfológicos dos estágios imaturos de Automeris naranja Schaus (Lepidoptera, Saturniidae, Hemileucinae). Revista Brasileira de Zoologia, vol. 24, no. 3, pp. 537-545. http://dx.doi. org/10.1590/S0101-81752007000300001.

SPECHT, A., CORSEUIL, E. and FORMENTINI, A.C., 2008. Saturniidae, Hemileucinae. In: A. SPECHT, E. CORSEUIL and H.B. ABELLA, org. Lepidópteros de Importância Médica - Principais espécies no Rio Grande do Sul. Pelotas: USEB, pp. 81-131.

SPECHT, A., CORSEUIL, E., BENEDETTI, A.J., POLETTO, G. and FORMENTINI, A.C., 2009. Aspectos biológicos e morfológicos de Leucanella viridescens (Lepidoptera: Saturniidae: Hemileucinae). Zoologia, vol. 26, no. 1, pp. 25-31. http://dx.doi. org/10.1590/S1984-46702009000100005.

SPECHT, A., FORMENTINI, A.C. and BENEDETTI, A.J., 2010. Biology and morphology of Molippa cruenta (Lepidoptera: Saturniidae) in the laboratory. Zoologia, vol. 27, no. 3, pp. 347352. http://dx.doi.org/10.1590/S1984-46702010000300005.

SPECHT, A., LORINI, L.M., FRONZA, E. and POLETTO, G., 2011. Biological aspects of Periga circumstans Walker, 1855 (Lepidoptera: Saturniidae: Hemileucinae) with larvae reared on khaki and mate-plant leaves. Brazilian Journal of Biology = Revista Brasileira de Biologia, vol. 71, no. 4, pp. 1015-1022. http://dx.doi.org/10.1590/S1519-69842011000500022.

SPECHT, A., FRONZA, E., COLOMBI, E.E., FORMENTINI, A.C. and CORSEUIL, E., 2012. Aspects of the biology and morphology of Dirphia dol osa Bouvier, 1929 (Lepidoptera: Saturniidae: Hemileucinae). Biota Neotropica, vol. 12, no. 4, pp. 21-28. http://dx.doi.org/10.1590/S1676-06032012000400001.

STEHR, F.W., 1987. Ordem Lepidoptera. In: F.W. STEHR, ed. Insetos imaturos. Dubuque: Kendall/Hunt, pp. 288-305.

ZANUNCIO, T.V., ZANUNCIO, J.C., MEIRA, I.A. and ARAÚJO, F.S., 1994. Caracterização das fases larval e adulta de Dirphia avicula (Lepidoptera: Saturniidae) em folhas de Eucalyptus urophylla. Revista Árvore, vol. 18, no. 2, pp. 153-158.

ZENKER, M.M., SPECHT, A., FRONZA, E., POLETTO, G., MARCON, F., FORMENTINI, A.C. and GEDOZ, M., 2013. Biology and life table of Dirphia araucariae (Lepidoptera: Saturniidae): A herbivore of potentially high impact on Araucaria angustifolia. Zoologia, vol. 30, no. 2, pp. 143-150. http://dx.doi. org/10.1590/S1984-46702013000200004.

WOLFE, K.L. and BALCÁZAR-LARA, M.A., 1994. An illustrated description immature stages of Lonomia electra (Druce, 1886) (Lepidoptera: Saturniidae, Hemileucinae). Nachrichten des Entomologischen Vereins Apollo, vol. 15, no. 3, pp. 383-392. 